Bangladesh J. Plant Taxon. 15(2): 81-87, 2008 (December)

(C) 2008 Bangladesh Association of Plant Taxonomists

\title{
ADDITION TO OEDOGONIACEOUS ALGAE OF BANGLADESH: BULBOCHAETE AGARDH
}

\author{
Sabrina Naz ${ }^{1}$, Shah Md. Golam Gousul Azam, Umma Nahar \\ AND NASRIN JAHAN DiBA \\ Department of Botany, University of Rajshahi, Rajshahi 6205, Bangladesh \\ Keywords: Oedogoniales, Bulbochaete, New records, Bangladesh
}

\begin{abstract}
A total of nine taxa of Bulbocheate Agardh are reported from the north-west Barind tract of Bangladesh as new records for the country. These are Bulbochaete crassa Pringsh., $B$. debaryana Wittr. \& Lund. in Wittr., B. elatior Pringsh. var. elatior, B. iyengarii Sarma \& Mukh., B. keralense Venk. \& Natr., B. minuta West \& West, B. nana Wittr. var. chungkingensis Jao, B. pygmaea Pringsh. var. erecta Jao, and B. suberecta (Coll.) Tiff.
\end{abstract}

\section{Introduction}

The Oedogoniales is a unusual, highly specialized order of green algae. Morphologically Oedogonium, Oedocladium and Bulbochaete are markedly different from each other. They have no obvious ancestors, several other features common to other green algae (e.g. possession of the phycoplast) place them in the Chlorophyta (Mattox and Stewart 1984). Preliminary molecular data (Booton et al. 1998) confirm that they constitute a monophyletic, taxonomically isolated clade. Further, these data also provide the fact that Bulbochaete could be more basally placed phylogenetically than the other two genera. Gonzalves (1981) reported 109 species of the genus Bulbochaete from all over the world which was further updated by Mrozinska (1985), who reported a total of 113 species.

So far 14 taxa of Bulbochaete have been reported from Bangladesh (Islam and Sarma 1965, Islam 1972, Islam 1979, Aziz et al. 1991, Zaman 1991, Hasan 2000). In a recent investigation into some freshwater habitats of north-west Barind tract of Bangladesh recorded nine taxa of Bulbochaete which have not been reported from Bangladesh earlier. The present paper portrays illustrated accounts of these taxa.

\section{Materials and Methods}

The present study was carried out in the north-west Barind tract situated in between 88. $2^{\circ}-89.2^{\circ} \mathrm{E}$ longitude and $24.6^{\circ}-25.2^{\circ} \mathrm{N}$ latitude of Bangladesh from November 2000 to March 2005. The descriptions and identification of all studied taxa are based upon the investigation of fertile, mature specimens collected between the $1^{\text {st }}$ week of November and $1^{\text {st }}$ week of March. The present study has concentrated on the Bulbochaete specimens growing on aquatic plants including charophytes. All the collected specimens were preserved

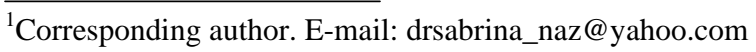


in Transeau's solution. Camera lucida drawings were made at 400× magnification under a Reichert microscope (Nr. 309 209). Photomicrographs were taken by a Vivitar V3200 camera.

\section{Taxonomic enumeration}

1. Bulbochaete crassa Pringsh.

(Pl. 1, Figs 9a-c; Pl. 2, Fig. 6)

(Gonzalves 1981, 639, 10: 63)

Nannandrous, gynandrosporous, vegetative cells 16-19 × 40-58 $\mu \mathrm{m}$, division of suffultory cell median or a little above median. Oogonium subdepressed-globose to globose patent, situated below a terminal setae, $50 \times 39-43 \mu \mathrm{m}$. Oospore $46 \times 35 \mu \mathrm{m}$, outer layer of spore wall scrobiculate, androsporangia up to 3 -seriate, scattered, $12 \times 13 \mu \mathrm{m}$. Dwarf males a little longer than the oogonia, $10 \times 40 \mu \mathrm{m}$. Antheridium unicellular, exterior, $9 \times 20 \mu \mathrm{m}$.

Material studied: Col. No. Bulbo-074, 12 February 2002, Dargahpara near Kakanhat at Godagari, Rajshahi, filaments attached to Hygroryza aristata (Retz.) Nees ex Wight \& Arn.

Distribution: North America: United States (Massachusetts, Ohio, Wisconsin). Europe: Austria, Czechoslovakia, Germany, Poland, Switzerland (Gonzalves 1981, Mrozinska 1985).

2. Bulbochaete debaryana Wittr. \& Lund. in Wittr.

(Pl. 1, Fig. 1; Pl. 2, Figs 1, 7)

(Saito and Yamagishi 1973, 1: 1-2, 2: 5; Gonzalves 1981, 587, 10: 3)

Monoecious, macrandrous, vegetative cells 13-20 × 22-32 $\mu \mathrm{m}$. Oogonium ellipsoid, situated below a vegetative cell or terminal setae. Oogonia 28-30 $\times 45-50 \mu \mathrm{m}$. Oospores $26-28 \times 36-48 \mu \mathrm{m}$. Antheridium single or up to 3, 10-12 $\times 5-8 \mu \mathrm{m}$.

Material studied: Col. No. Bulbo-013, 2 March 2005, Andhasura beel in Naogaon, filaments attached to Nitella hyalina Agardh.

Distribution: North America: Alaska, Canada, Greenland. Europe: Poland, Sweden, U.S.S.R. (Estonian S.S.R.; Latvian S.S.R.) (Gonzalves 1981).

\section{Bulbochaete elatior Pringsh. var. elatior}

(Pl. 1, Fig. 3; Pl. 2, Fig. 2)

(Gauthier-Lievre 1963-64, 237, 25: 4Aa; Gonzalves 1981, 602, 10: 22A)

Nannandrous, gynandrosporous, vegetative cells slender, 10.0-16.5 $\times$ 29.7-33.0 $\mu \mathrm{m}$, division of suffultory cell basal. Oogonium depressed-globose, erect 42.9-45.2 × 33-36 $\mu \mathrm{m}$. Oospore globose, 33-42 $\times 26-30 \mu \mathrm{m}$, spore wall smooth. Androsporangia single or two, epigynous, rarely scattered, 7-10 $\times 10 \mu \mathrm{m}$. Dwarf male situated on the suffultory cell, stipe straight, $8-9 \times 16-20 \mu \mathrm{m}$; antheridium exterior, unicellular, 6-8 $\times$ 9-11 $\mu \mathrm{m}$; basal division of the suffultory cell the exterior antheridium and the short dwarf males are the distinguishing characters of this species. Oogonia usually erect. 
Mrozinska (1985) described this variety as two forma (f. elatior and f. pumila Hirn); our material's morphology resembles with the description and measurement of B. elatior var. elatior f. pumila Hiorn.
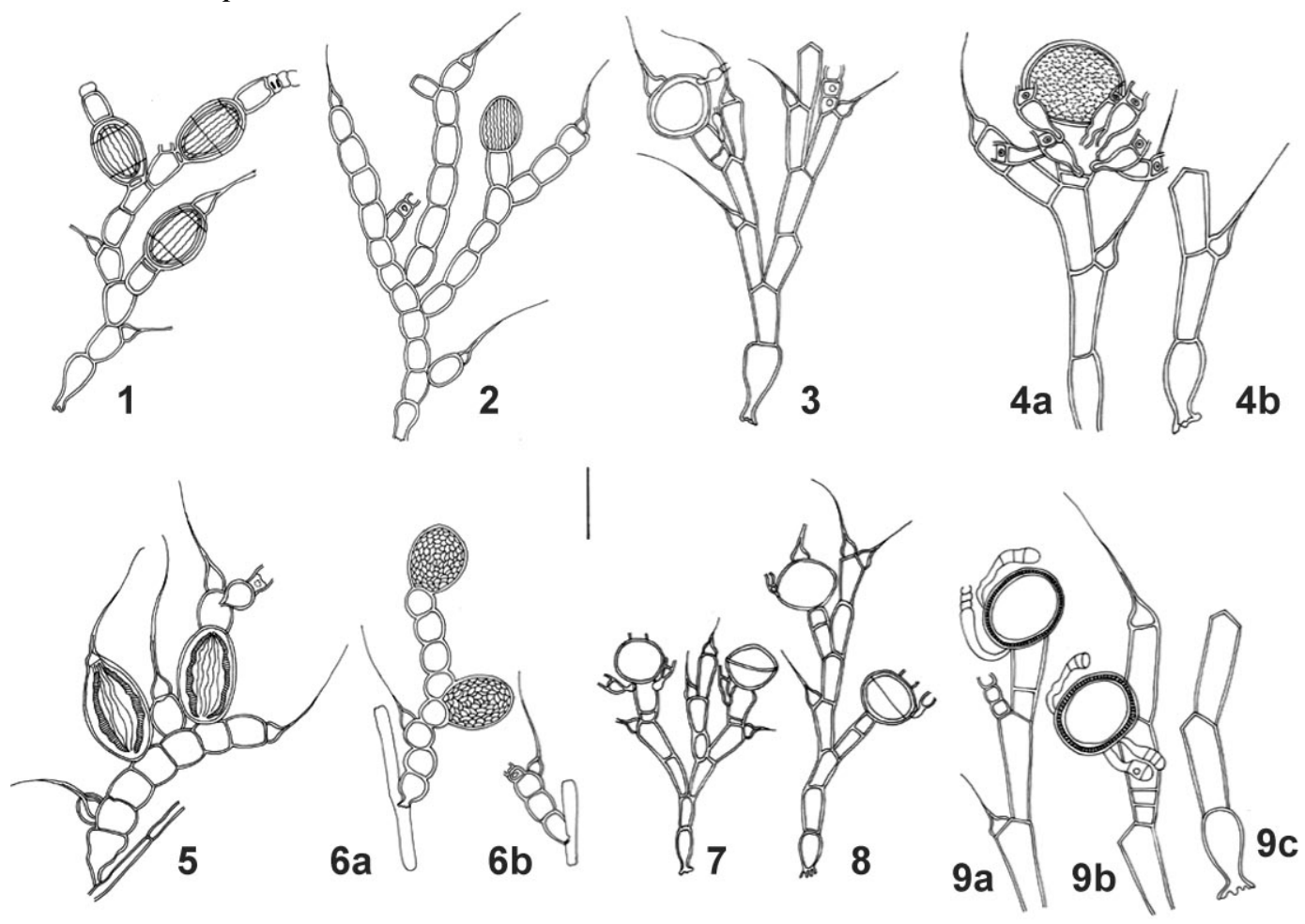

Plate 1

Figs 1-9. 1. Bulbochaete debaryana, 2. B. nana var. chungkingensis, 3. B. elatior var. elatior, 4a, b. B. keralense, 5. B. pygmaea var. erecta, 6a, b. B. iyengarii, 7. B. minuta, 8. B. suberecta, 9a-c. B. crassa. $($ Scale $=50 \mu \mathrm{m})$

Material studied: Col. No. Bulbo-016, 1 January 2001, Uddran Dighi at Debour at Saphahar, Naogaon, filaments attached to Cyperus tagetiformis Roxb.

Distribution: Africa: Chad, Guinea, Ivory Coast, Malagasy Rep., Senegal, Tanzania, Upper Volta. North America: United States (Massachusetts, Michigan). Central America: Panama Canal. South America: Brazil. Asia: Burma, India (Ankola in Karnataka), Sri Lanka. Europe: Austria, Germany, Poland, Sweden, U.S.S.R. (Russian S.F.S.R., Ukrainian S.S.R.). Oceania: Australia (Queensland, Arnhem Land, New Caledonia). West Indies: Puerto Rico (Gonzalves 1981). 
4. Bulbochaete iyengarii Sarma \& Mukherjee (Pl. 1, Figs 6a, b; Pl. 2, Fig. 3)

(Sarma and Mukherjee 1990, 55-57, 1: 1-7)

Macrandrous, heterothallic, vegetative cells moniliform to short cylindric, 13.2-14.0 $\times 13.0-16.5 \mu \mathrm{m}$. Basal cell pointed at the base, basal cell blunt. Oogonium ellipsoid, brown, erect, $33 \times 22 \mu \mathrm{m}$. Oospore of same shape as oogonium, normally completely filling the oogonium, oospore $30.0 \times 19.8 \mu \mathrm{m}$ in diameter, spore wall three-layered, outer layer smooth, median layer areolate. Antheridium erect, 1-2 seriate, $33 \times 9 \mu \mathrm{m}$, division horizontal.

Note: This species resembles B. macrandria Ley (Gonzalves 1981, Mrozinska 1985) in its shape and size of the vegetative cell, but differs in basal cell. In this species basal cell is blunt, but in B. macrandria basal cell is conical; ornamentation of oospore in $B$. iyengarii is areolate, but scrobiculate in B. macrandria.

Materials studied: Col. No. Bulbo-004, 18 November 2000, Chagati Pond at Godagari, Rajshahi, filaments attached to Nymphaea nouchali Burm.; Col. No. Bulbo-013, 2 March 2005, Andhasura beel in Naogaon, filaments attached to Nitella hyalina.

Distribution: India (Rukni in Purulia District, Amtala in Murshidabad District) (Sarma and Mukherjee 1990).

5. Bulbochaete keralense Venk. and Natr.

(Pl. 1, Figs 4a, b; Pl. 2, Fig. 9)

(Gonzalves 1981, 646, 10: 70)

Nannandrous, idioandrosporous, vegetative cells cylindric, 13.2-18.0 $\times 24-33 \mu \mathrm{m}$, division of suffultory cell basal. Oogonium depressed-globose, erect, situated below a terminal seta, 36.6-29.0 $\times 79-33 \mu \mathrm{m}$. Oospore is completely filling the oogonium, 29.7$33.0 \times 26.4-29.0 \mu \mathrm{m}$, spore wall scrobiculate. Dwarf males situated on the suffultory cell near the oogonium or on the oogonium, 9.9-11.9 $\times 22.7-24.4 \mu \mathrm{m}$. Antheridium single or two, exterior, $8.0 \times 7.8 \mu \mathrm{m}$.

Material studied: Col. No. Bulbo-060, 22 November 2002, Dargapara near Kakanhat at Godagari in Rajshahi, filaments attached to Corchorus olitorius L. and Cyperus tagetiformis Roxb.

Distribution: India (Kottarakara in Kerala) (Gonzalves 1981).

\section{Bulbochaete minuta West \& West}

(Pl. 1, Fig. 7; Pl. 2, Fig. 8)

(Gauthier-Lievre 1963-64, 240, 26: 42; Gonzalves 1981, 604, 10: 24)

Nannandrous, gynandrosporous, vegetative cells 9-13 $\times 16-26 \mu \mathrm{m}$, division of suffultory cell basal. Oogonium depressed-globose, erect or patent, situated below an androsporangium, $30 \times 26 \mu \mathrm{m}$, division median or nearly so. Oospore depressed-globose, $27 \times 25 \mu \mathrm{m}$, spore wall smooth. Androsporangium unicellular, epigynous. Dwarf males situated on suffultory cell, $7 \times 16 \mu \mathrm{m}$, stipe curved. Antheridium unicellular, exterior. 
Note: In B. minuta the dwarf male is situated on the suffultory cell, but in $B$. suberecta (Coll.) Tiff., dwarf male is situated on the oogonium.

Material studied: Col. No. Bulbo-027, 1 November 2001, Naogaon district in Sapahar at Mungroil, filaments attached to Scirpus articulatus (L.) Palla.

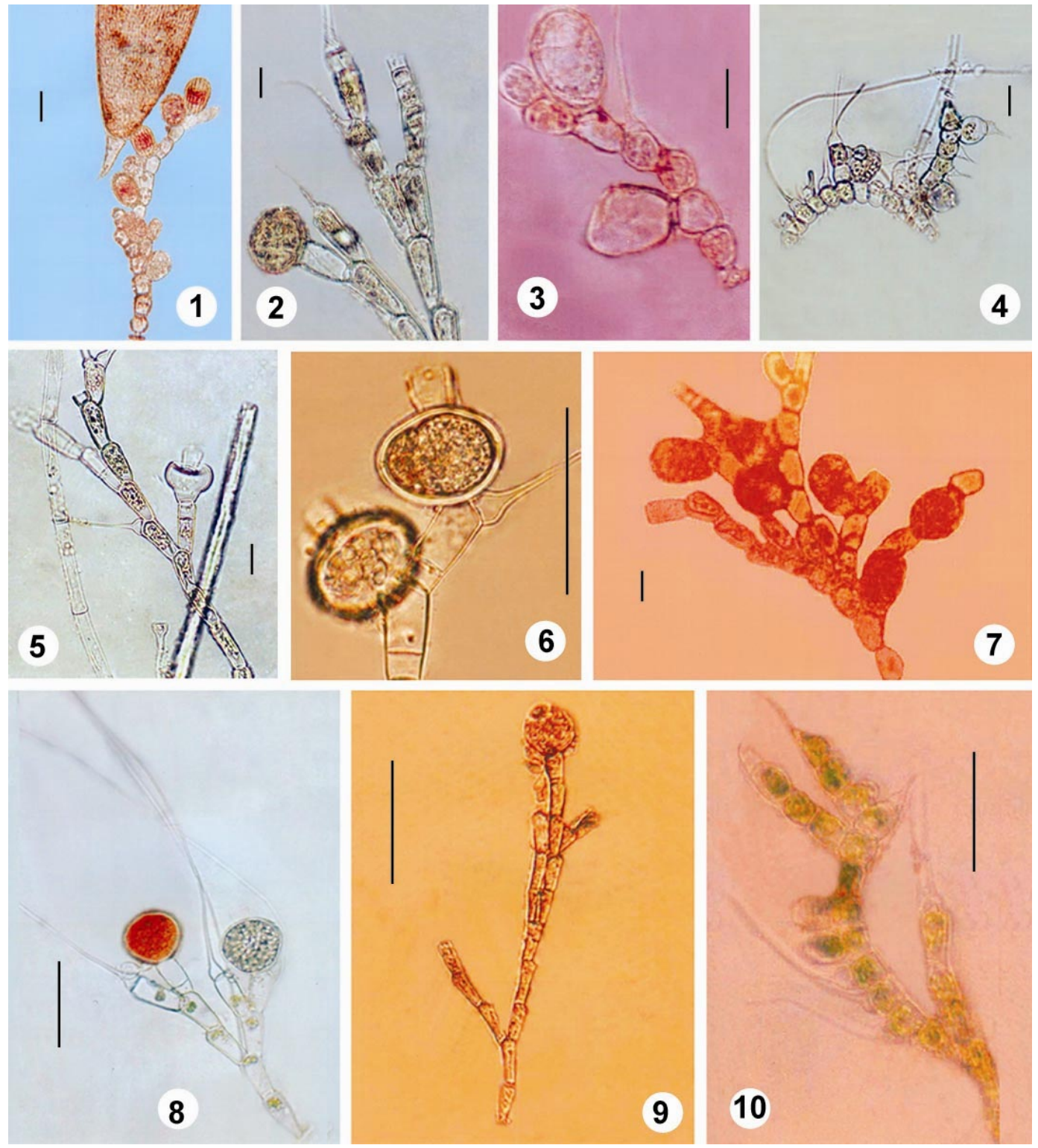

Plate 2

Figs 1-10. 1,7. Bulbochaete debaryana, 2. B. elatior var elatior, 3. B. iyengarii, 4. B. pygmaea var. erecta, 5. B. suberecta, 6. B. crassa, 8. B. minuta, 9. B. keralense, 10. B. nana var. chungkingensis. (Scales $=50$ $\mu \mathrm{m})$ 
Distribution: Africa: Congo, Ivory Coast, Malagasy, Mali, Upper Volta. North America: United States (Florida, Massachusetts, Michigan, New England, Oklahoma). Asia: China, India (Devarayi in Karnataka), Sri Lanka (Gonzalves 1981).

\section{Bulbochaete nana Wittr. var. chungkingensis Jao}

(Pl. 1, Fig. 2; Pl. 2, Fig. 10)

(Gonzalves 1981, 592, 10: 8B)

Macrandrous, homothallic, vegetative cells 13-14 × 18-23 $\mu \mathrm{m}$. Oogonium somewhat obovoid-ellipsoid, rarely ellipsoid, broader than that of the type, $23 \times 33 \mu \mathrm{m}$. Antheridium smaller than that of the type, 8-10 $\times 4-6 \mu \mathrm{m}$. Outer layer of spore wall smooth; median layer longitudinally costae. Antheridium single or in twos, erect or scattered, $7 \times 5 \mu \mathrm{m}$.

Material studied: Col. No. Bulbo-067, 15 December 2002, Devipur at Mahadebpur in Naogaon district, filaments attached to deep water paddy straw (Oryza rufipogon Griffiths).

Distribution: According to Mrozinska (1985) this variety has so far been reported only from China.

\section{Bulbochaete pygmaea Pringsh. var. erecta Jao \\ (Pl. 1, Fig. 5; Pl. 2, Fig. 4)}

(Gauthier-Lievre 1963-64, 225, 16: a-f; Gonzalves 1981, 621, 10: 45A)

Nannandrous, gynandrosporous, filaments short, usually less than ten-celled, unbranched or with one or two-celled branches, vegetative cells $13 \times 11 \mu \mathrm{m}$, basal cell $13 \times 16 \mu \mathrm{m}$. Division of suffultory cell lacking. Oogonium ellipsoid, erect, usually next to the basal cell, very rarely terminal or patent, below vegetative cells or setae, 21-24 $\times$ 33-36 $\mu \mathrm{m}$. Oospore 19-22 $\times 30 \mu \mathrm{m}$; presence of longitudinal ribs on spore wall. Androsporangia single or in twos, scattered, $10 \times 3 \mu \mathrm{m}$. Dwarf male situated near the oogonium, stripe $13 \times 20 \mu \mathrm{m}$. Antheridium exterior.

Material studied: Col. No. Bulbo-045, 2 November 2001, Chakla at Mahadebpur in Naogaon district, filaments attached to Enhydra fluctuans Lour.

Distribution: The United States (Massachusetts) (Gonzalves 1981, Mrozinska 1985).

\section{Bulbochaete suberecta (Coll.) Tiff.}

(Pl. 1, Fig. 8; Pl. 2, Fig. 5)

(Gonzalves 1981, 656, 10: 83)

Nannandrous, gynandrosporous, vegetative cells 24-36 $\times 10-13 \mu \mathrm{m}$, division of suffultory cell supramedian to superior. Oogonium depressed-globose, usually erect, situated below an androsporangium, $33 \times 29 \mu \mathrm{m}$, division median. Oospore $30 \times 27 \mu \mathrm{m}$, spore wall finely scrobiculate. Androsporangium single, epigynous, dwarf male situated on the oogonium, $16 \times 10 \mu \mathrm{m}$. Antheridium $7 \times 9 \mu \mathrm{m}$. 
Material studied: Col. No. Bulbo-025, 1 November 2001, Mohishdanga at Sapahar upazilla in Naogaon district, filaments attached to Cyperus tagetiformis.

Distribution: North America (Massachusetts) (Gonzalves 1981, Mrozinska 1985).

\section{References}

Aziz, A., Alam, J. and Islam, A.K.M. Nurul 1991. Studies on the members of Oedogoniales epiphytic on deepwater rice plants near Sonargaon, Bangladesh. Dhaka Univ. Stud. Part E 6(2):119-123.

Booton, G.C., Floyd, G.L. and Fuerst, P.A. 1998. Origins and affinities of the green algal Orders Chaetophorales and Oedogoniales based on 18S rRNA gene sequences. J. Phycol. 34: 312-318.

Gonzalves, F.A. 1981. Oedogoniales. ICAR. New Delhi, pp. 1-757.

Gauthier- Lievre, L. 1963-64. Oedogoniaceae Africains. Nova Hedwigia 7: 208-255.

Hasan, M.A. 2000. Assessment of diversity of algal plants in Chalan beel in relation to physico-chemical conditions. Ph.D. Thesis, Rajshahi University, pp. 1-420.

Islam, A.K.M. Nurul 1972.The genus Bulbochaete in Bangladesh. Bangladesh J.Bot. 1(1\&2): 1-12.

Islam, A.K.M. Nurul 1979. Addition to the list of Oedogoniaceae from Bangladesh. Dacca Univ. Stud. B. 27(1): 47-52.

Islam, A.K.M. Nurul and Sarma, P. 1965. New and rare species and varieties of the Oedogoniales from Dacca District, East Pakistan. Pak. Jour. Biol. Agri. Sci. 8(1):169-188.

Mattox, K.R. and Stewart, K.D. 1984. A classification of the green algae: a concept based on comparative cytology. In: Irvine, D.E.G. and John, D.M. (eds), Systematics of the Green Algae, pp. 29-72. Academy Press, London.

Mrozinska, T. 1985. Süßwasserflora von Mitteleuropa Chlorophyta VI Oedogoniophyceae Oedogïoniales. VEB Gustav Fischer Verlag Jena, pp. 1-624.

Sarma, P. and Mukherjee, D. 1990. A new species of macrandrous heterothallic Bulbochaete (B. iyengarii sp. nov.) from west Bengal, India. In: Rajarao, V.N. (ed.), Perspectives in Phycology, pp. 55-57. Today \& Tomorrow's Printers \& Publishers, New Delhi, India.

Saito, E. and Yamagishi, T. 1973. Studies on some Bulbochaete and Oedogonium in the Alaskan, Canada and Greenland. Gen. Educ. Rev., Coll. Agr. \& Vet. Med., Nihon Uni. 9: 24-31.

Zaman, M. 1991. Studies on the algal flora of Chalan-beel in relation to its physico-chemical conditions. Ph.D. Thesis, Rajshahi University, pp. 1-550. 